\title{
Does lactobacillus vaccine for trichomoniasis, Solco Trichovac, induce antibody reactive with Trichomonas vaginalis?
}

\author{
JOHN F ALDERETE
}

From the Department of Microbiology, University of Texas Health Science Center, San Antonio, Texas, USA

SUMMARY Solco Trichovac is a vaccine of Lactobacillus acidophilus developed for treating trichomoniasis. The efficacy of the vaccine is reportedly due to cross reacting antibody being produced in people immunised with the lactobacillus bacteria. Several techniques, including enzyme linked immunosorbent, indirect immunofluorescence, immunoblot, and radioimmunoprecipitation assays were used to assess the extent of antigenic cross reactivity between Lactobacillus acidophilus and Trichomonas vaginalis. Data show a lack of antigenic relatedness between the Solco Trichovac lactobacilli and several strains of $T$ vaginalis. Furthermore, antiserum to $L$ acidophilus failed to inhibit trichomonad cytadherence or host cell killing, as is suggested by the producers of the Solco Trichovac vaccine.

Trichomoniasis continues to be a major sexually transmitted disease in the world. With the emergence of resistance to drugs in strains of Trichomonas vaginalis, 'the development of a vaccine represents an important and necessary step towards eradication or at least control of this disease.

The use of Lactobacillus acidophilus as a vaccine for $T$ vaginalis infections has received attention. ${ }^{2-6}$ Reports indicate that the successful immunisation of women is due to the generation of antibody that recognises determinants common to antigens of both lactobacillus and the pathogenic human trichomonads. ${ }^{56}$ Data conflict about the extent and nature of such antigenic relatedness in the lactobacillus and $T$ vaginalis organisms. ${ }^{5-7}$ Using several modern techniques and biofunctional assays, I obtained data indicating that no cross reactivity exists between the lactobacillus used in the Solco Trichovac vaccine ${ }^{2-6}$ and the protozoan responsible for trichomoniasis.

\section{Materials and methods}

TVAGINALIS STRAINS, LACTOBACILLI, AND ANTISERA

All the $T$ vaginalis strains had been used in previous studies. $^{8-15}$ For example, NYH 286 is a common

Address for reprints: $\mathrm{Dr}$ John $\mathrm{F}$ Alderete, Department of Microbiology, UTHSC-SA, 7703 Floyd Curl Drive, San Antonio, Texas 78284-7758, USA

Accepted for publication 16 June 1987 laboratory strain that has been extensively evaluated by all the assays used in this report. The Solco Trichovac lactobacillus was a kind gift from Drs Valent and Demeš of the Institute of Parasitology, Comenius University at Bratislava, Czechoslovakia. Four rabbits were individually injected subcutaneously and intramuscularly with $1 \mathrm{ml}$ final volume containing $7 \times 10^{8}$ lactobacilli prepared in Freund's complete adjuvant. At two week intervals thereafter they were given two booster immunisations with the lactobacillus in Freund's incomplete adjuvant. The concentration of antibody in rabbit serum was monitored by an enzyme linked immunosorbent assay (ELISA) as described below. Prebleed serum samples from the immunised rabbits served as controls.

\section{IMMUNOLOGICAL ASSAYS TO TEST FOR}

ANTIGENIC CROSS REACTIVITY

Four assays were used to assess whether antisera to the Solco Trichovac $L$ acidophilus detected $T$ vaginalis antigens. To insure that rabbits indeed produced antibody to lactobacillus, the bacteria in the original vaccine suspension of $7 \times 10^{9}$ bacteria per $\mathrm{ml}$ were diluted 10 -fold up to $10^{-6}$. Volumes of $50 \mu \mathrm{l}$ of the various dilutions were added to individual wells of microtitre plates and allowed to dry, and $100 \%$ ethanol was added as a fixative. " Sera from all four rabbits injected with lactobacillus were then individually tested for reactivity with the bacteria coated microtitre wells. After antibody had been 


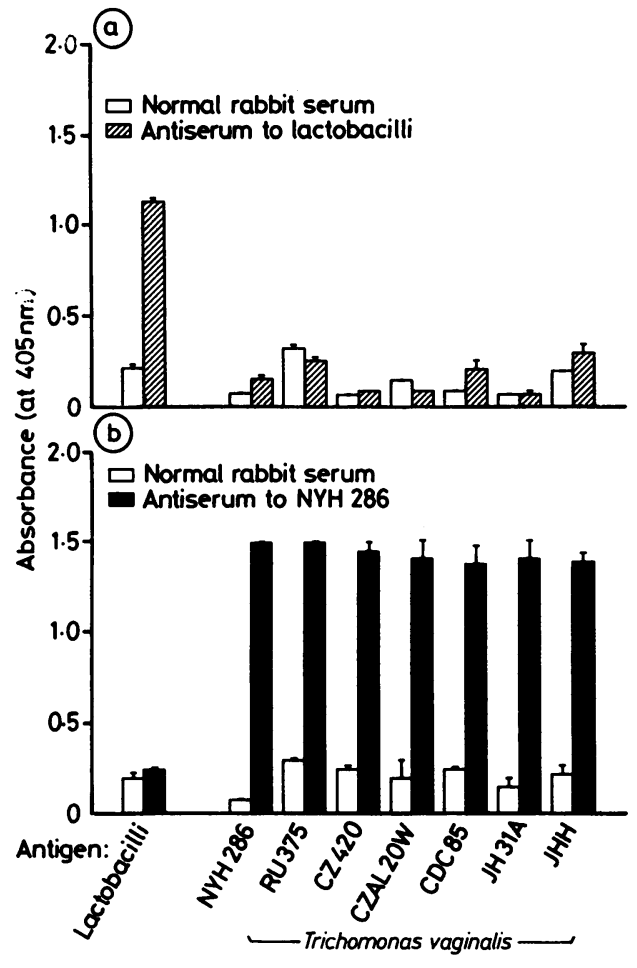

Fig 1 Results of enzyme linked immunosorbent assay (ELISA) using rabbit antiserum generated against the Solco Trichovac lactobacillus vaccine (a) and Trichomonas vaginalis strain NYH 286 (b). Abscissa shows seven trichomonal isolates and lactobacilli, which were fixed to microtitre well surfaces for screening with antiserum. Prebleed normal rabbit serum was used as a control. For this experiment, $7 \times 10^{5}$ lactobacilli were fixed to individual wells of microtitre plates. All sera were diluted $10^{-3}$.

incubated with antigen for two hours at $4^{\circ} \mathrm{C}$, the wells were washed with phosphate buffered saline (PBS) and incubated for one hour at $37^{\circ} \mathrm{C}$ with goat anti-rabbit immunoglobulins conjugated with alkaline phosphatase. Lactobacillus antisera from all four rabbits diluted $10^{-2}$ and $10^{-3}$ yielded maximum reactions when $7 \times 10^{3}$ and $7 \times 10^{5}$ lactobacilli were used to coat the polyvinyl microtitre wells (fig 1 (a)). The antiserum $L$ acidophilus from the individual rabbits was then pooled for use in the experiments outlined. The procedure for using $T$ vaginalis organisms as the test antigen has been described previously."

Indirect immunofluorescence with live $T$ vaginalis parasites was performed using techniques reported previously. ${ }^{913-15}$ In this case, the rabbit antisera to lactobacillus were heat inactivated at $56^{\circ} \mathrm{C}$ for 15 minutes immediately before being added to trichomonads. Rabbit antiserum to $T$ vaginalis strain
NYH $286^{89}$ was used as a positive control to show fluorescence reactions.

Immunoblot $^{13}$ was performed with total trichloroacetic acid precipitated proteins of $T$ vaginalis strains $^{8}$ and the bovine trichomonad, Tritrichomonas foetus. ${ }^{16}$ Radioimmunoprecipitation assays using detergent extracts of both surface radiolabelled ${ }^{9}$ and intrinsically radiolabelled ${ }^{8}$ parasites were also performed using methods detailed elsewhere. ${ }^{891315}$ Antiserum $^{89}$ and monoclonal antibodies ${ }^{13-15}$ reactive with $T$ vaginalis protein antigens were used as positive controls for these assays.

\section{CYTADHERENCE AND CYTOTOXICITY ASSAYS}

Monolayers of HeLa cells incubated with trichomonads labelled with tritiated $\left({ }^{3} \mathrm{H}\right)$ thymidine ${ }^{10}{ }^{12}$ were used to study the effect of antiserum to lactobacillus on trichomonal cytadherence. Parasites were pretreated with up to $50 \%$ heat inactivated pooled antiserum to lactobacillus for different times up to one hour. The suspension of $T$ vaginalis containing the antiserum to lactobacillus was then added to cell monolayers ${ }^{12}$ and incubated in a $5 \%$ carbon dioxide humidified atmosphere for 30 minutes at $37^{\circ} \mathrm{C}$. Coverslips were then extensively washed in PBS before being immersed in scintillation vials containing the cocktail and having their radioactivity measured.

A quantitative colorimetric assay using $\mathrm{HeLa}$ cells in monolayer cultures was used to assess the extent of host cell killing. ${ }^{10}$ For these experiments, different concentrations of high titred antiserum to lactobacilli were included with the mixture of parasite and host cells throughout the 18 hour incubation. ${ }^{10}$

\section{Results}

ENZYME LINKED IMMUNOSORBENT ASSAY (ELISA) It was first necessary to show the presence of antibody

Table Antibody titration to two different concentrations of Solco Trichovac lactobacilli fixed to microtitre wells. Numbers are mean (SD) absorbances (at $405 \mathrm{~nm}$ ) of duplicate samples from three experiments*

\begin{tabular}{lll}
\hline & \multicolumn{2}{l}{ Concentrations of lactobacillif } \\
\cline { 2 - 3 } Dilutions of serum $\dagger$ & $7 \times 10^{5} / \mathrm{ml}$ & $7 \times 10^{4} / \mathrm{ml}$ \\
\hline $10^{-1}$ & $0.74(0.01)$ & $1.04(0.01)$ \\
$10^{-2}$ & $0.64(0.01)$ & $1.12(0.02)$ \\
$10^{-3}$ & $0.54(0.02)$ & $0.94(0.02)$ \\
$10^{-4}$ & $0.74(0.02)$ & $0.88(0.01)$ \\
$10^{-5}$ & $0.16(0.01)$ & $0.62(0.02)$
\end{tabular}

*Normal rabbit serum at $10^{1}, 10^{-3}$, and $10^{-5}$ dilutions gave mean (SD) absorbances of $0.25(0.01), 0.15(0)$, and $0.10(0)$, respectively, for $7 \times 10^{8}$ lactobacilli. Similar low level reactivity was observed for normal rabbit serum with all concentrations of lactobacilli.

Serum at 14 days after the final booster was used.

fOriginal concentration of bacteria was $7 \times 10^{9} / \mathrm{ml}$. 


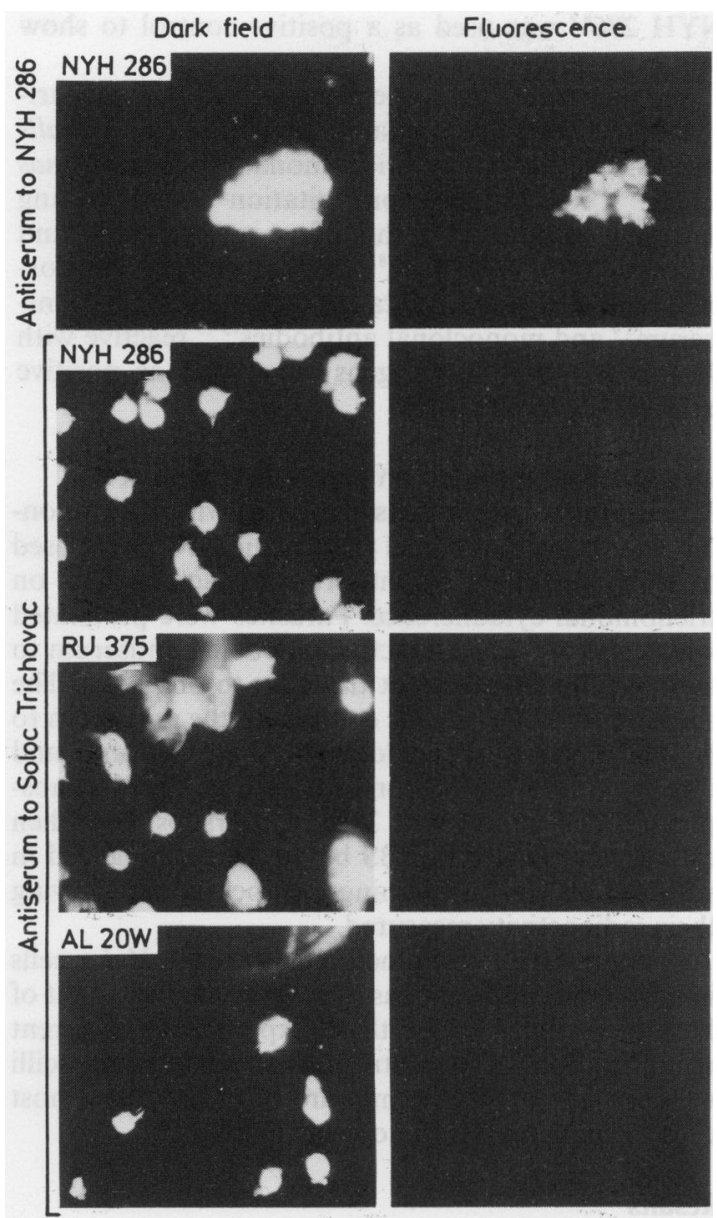

Fig 2 Indirect immunofluorescence and corresponding dark field pictures of Trichomonas vaginalis strains treated with antiserum to Solco Trichovac. As a positive control all strains were incubated with antiserum to strain $N Y H 286$, and a representative fluorescence of agglutinated $N Y H 286$ parasites is presented in the top panel. Prebleed control serum gave no fluorescence reactions with any of the strains as also seen with antiserum to Solco Trichovac.

to lactobacillus in sera of rabbits immunised with the Solco Trichovac vaccine. The table shows the high level of recognition of pooled rabbit antisera to the Solco Trichovac lactobacillus by different concentrations of $L$ acidophilus as antigen coating microtitre wells. The same antisera, however, failed to give a reaction greater than that of the control prebleed serum with seven $T$ vaginalis strains (fig 1 (a)). Antiserum to the trichomonal strain NYH 286, however, gave strong ELISA readings with all seven strains but failed to react with the lactobacilli coated wells (fig 1 (b)).
INDIRECT IMMUNOFLUORESCENCE

It was then important to test for any immunofluorescence of $T$ vaginalis with the pooled antiserum to lactobacillus. Figure 2 shows that, whereas rabbit antiserum to strain NYH 286 gave strong fluorescence of live organisms, antibody to the Solco Trichovac $L$ acidophilus gave no fluorescence with parasites of three strains, which indicated no trichomonad surface recognition.

\section{IMMUNOBLOT AND RADIOIMMUNOPRECIPITATION} ASSAYS

Fig 3 (a) shows many trichomonad protein antigens immobilised on nitrocellulose with rabbit antiserum to $T$ vaginalis strain NYH 286 . The extent of any trichomonad protein recognition of duplicate immunoblots incubated with antiserum to Solco Trichovac lactobacillus (b) equalled the minor reactivity obtained with prebleed control serum (c).

Finally, any cross reaction between antiserum to Solco Trichovac lactobacillus and radiolabelled $T$ vaginalis antigens was tested by the radioimmunoprecipitation assay (fig 4). Under no circumstances were trichomonad proteins labelled with either radioiodine $\left({ }^{125} \mathrm{I}\right)$ (surface) or radiosulphate (internal) $\left({ }^{35}\right.$ S) precipitated when Staphylococcus aureus bearing protein A was added to extracts containing antiserum to lactobacillus. Furthermore, antisera from two people immunised with the Solco Trichovac vaccine ${ }^{7}$ also failed to show any formation of antigen and antibody immune complexes (data not shown). On the other hand, the use of rabbit antiserum strain NYH $286^{89}$ or monoclonal antibody C20A3, which is known to react with a high molecular weight immunogen, ${ }^{13-15}$ readily resulted in the precipitation of appropriate protein(s). As expected, no reaction with parasite proteins was observed with prebleed control serum.

\section{CYTADHERENCE AND CYTOTOXICITY ASSAYS}

Antiserum to the lactobacillus vaccine may interfere with certain reactions with live parasites ${ }^{56}$ such as cytadherence ${ }^{12}$ and host cell killing. ${ }^{10} \mathrm{~A}$ report has also shown that host cells incubated with lactobacilli were less vulnerable to parasitism by $T$ vaginalis. ${ }^{17}$ Examination for possible inhibition of $T$ vaginalis parasitism and killing of host cells by the antiserum to $L$ acidophilus was therefore necessary. Pretreatment of parasites and adding antiserum to lactobacilli during incubation of trichomonads and host cells did not affect the extent of cytadherence or host cytotoxicity (data not shown). ${ }^{10} 12$ Levels of host cell parasitism and killing by $T$ vaginalis in the presence of antiserum to lactobacilli were equivalent to those seen either without the addition of exogenous serum or with prebleed serum. 


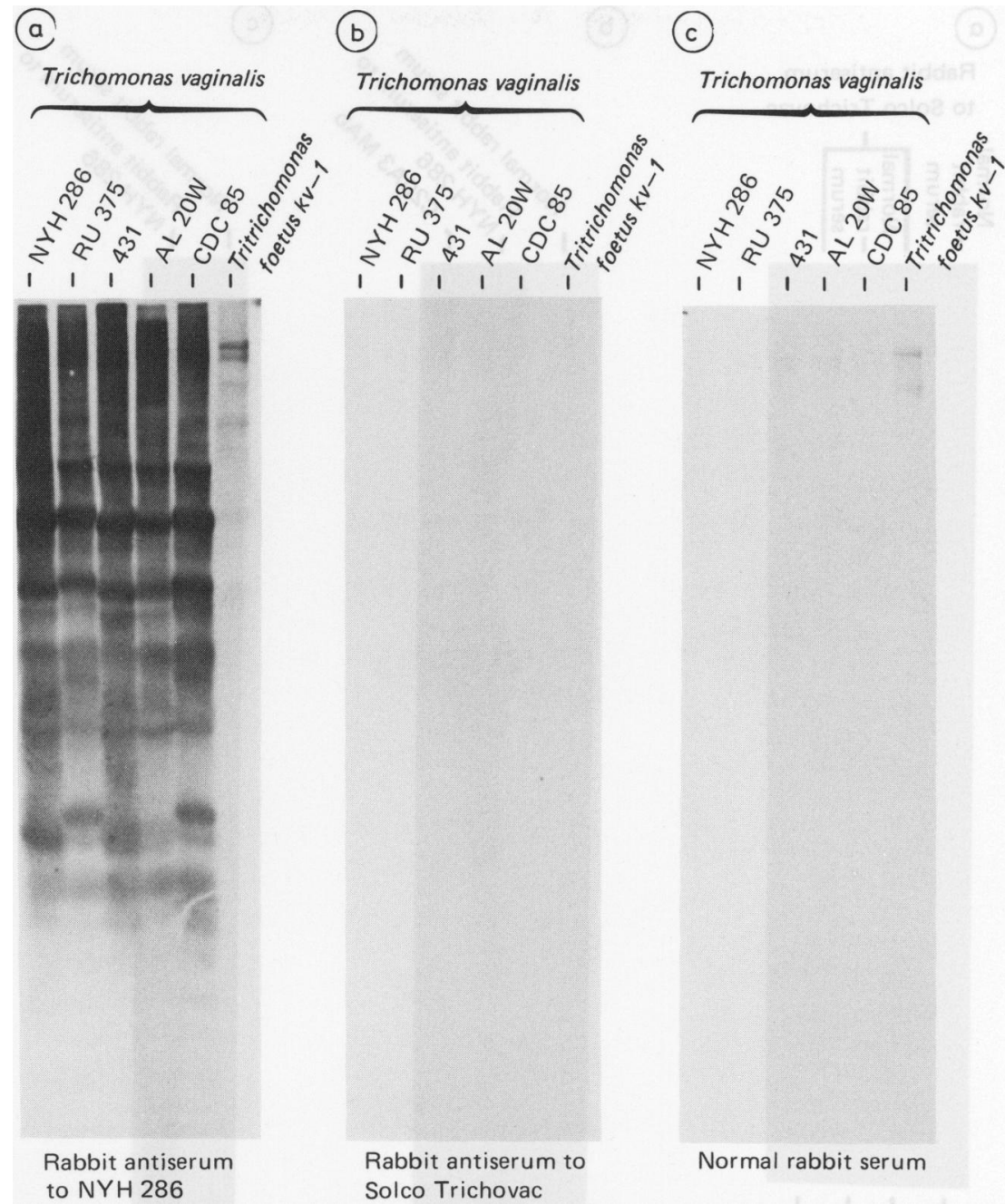

Fig 3 Immunoblot of various Trichomonas vaginalis strains (NYH 286, RU 375, 431, AL20W, and CDC85) and the bovine trichomonad, Tritrichomonas foetus $K V-1$, with antiserum to Solco Trichovac lactobacillus (b). Antiserum to strain $N Y H 286$ (a) and prebleed normal rabbit serum (c) were used as positive and negative controls, respectively, under the same experimental conditions.

\section{Discussion}

The Solco Trichovac vaccine contains a mixture of "aberrant" L acidophilus, ${ }^{2}$ and its immunotherapeutic effect has been ascribed to possible cross reactions between the lactobacillus and surface structures of the pathogenic human trichomonads. ${ }^{256}$ Thus, antibody would be produced that would not only interfere with biofunctional aspects of $T$ vaginalis, such as cytadherence and contact dependent host cytotoxicity, ${ }^{1012}$ but might neutralise the parasite, as has been described..$^{14}$ It was therefore interesting to assess the possible nature of cross reactivity between high titred rabbit antiserum to the Solco Trichovac lactobacillus and trichomonad proteins. Detection of common epitopes in trichomonad molecules and $L$ acidophilus would give considerable insight into the immunogens of $T$ vaginalis that could be studied further as vaccine candidates. Alternatively, such antigenic commonality between the pathogenic human trichomonads and possibly bacteria of the normal flora ${ }^{1256}$ would be relevant to issues dealing with the ecology of the normal flora during this infection and after vaccination. 
a

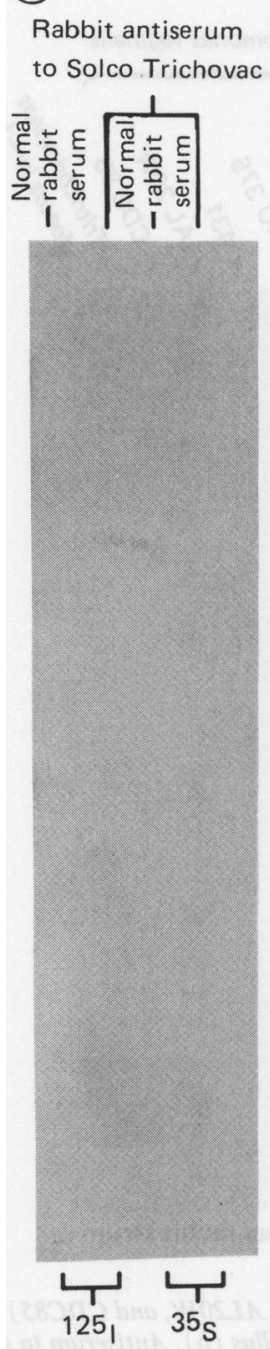

(b)

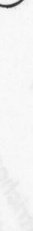

(c)
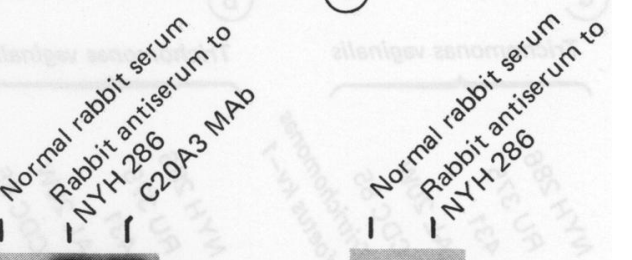

1
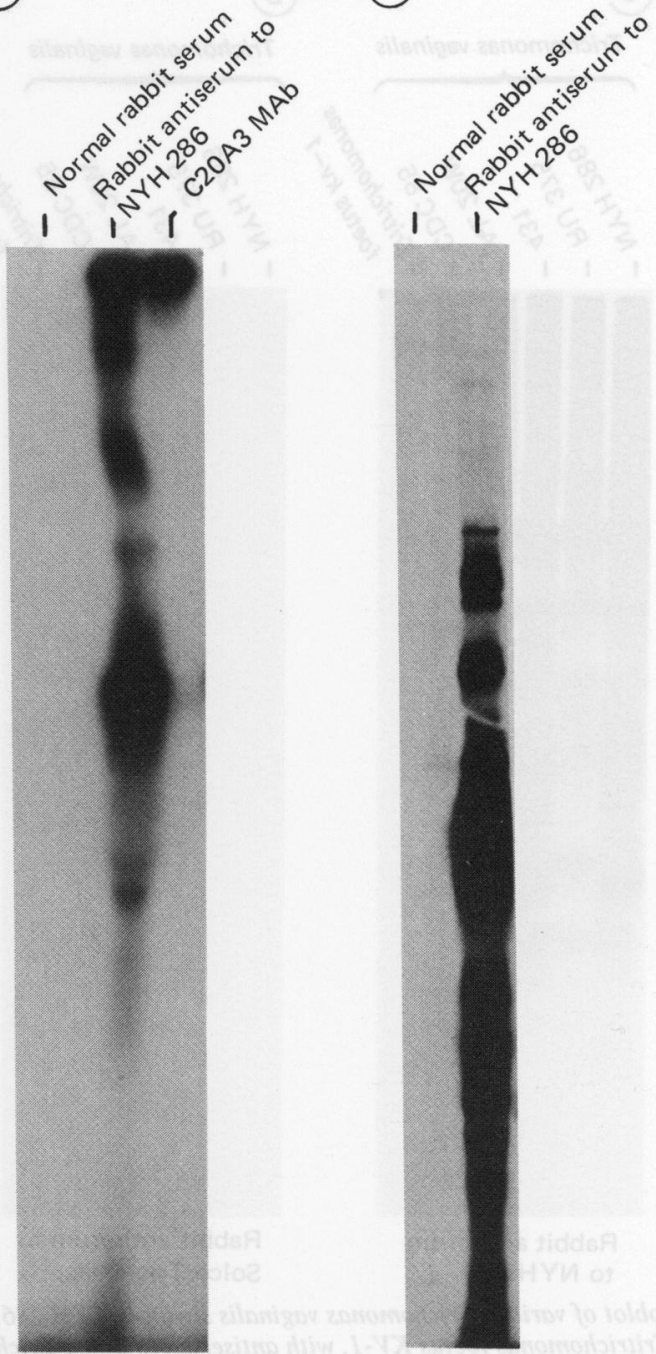

Fig 4 Radioimmunoprecipitation assay (a) using detergent extracts of surface iodinated ( ${ }^{125} I$ ) trichomonads and those internally labelled with radiosulphate ${ }^{35} S$ ) incubated with rabbit antiserum to Solco Trichovac lactobacillus. Prebleed normal rabbit serum served as a negative control. Rabbit antiserum to Trichomonas vaginalis strain NYH 286 and a monoclonal antibody $(M A b)$ designated $C 20 A 3$, which recognises a trichomonad surface immunogen, were used in duplicate preparations of detergent extracts labelled with $(a){ }^{125} I$ and $(b){ }^{35} S$.

Several immunological assays, including highly sensitive and specific immunoblot and radioimmunoprecipitation techniques, as well as two biofunctional assays, were used in this study. No evidence was obtained to indicate any cross reactivity between antigenic epitopes of $T$ vaginalis and the Solco Trichovac lactobacillus. These data suggest strongly that any protection in man claimed by the producers of the Solco Trichovac vaccine ${ }^{2}$ is not due to direct antibody interference or neutralisation of the parasite. ${ }^{56}$ Our results and those of others ${ }^{7}$ suggest that non-specific immune mechanisms are more probably responsible for any dimunition or resolution of trichomoniasis or its symptoms in patients. Clearly, much more research appears to be warranted before allowing large scale human vaccination with bacteria originally derived from the urogenital and vaginal tract of women.

Finally, the inability of antiserum to lactobacillus to inhibit host cytadherence and cytotoxicity is especially noteworthy in the light of a report showing that 
pretreatment of cell monolayers with lactobacilli decreased trichomonal parasitism levels. ${ }^{17}$ These results now appear to be attributable to steric considerations imposed on the host cell surface when intact bacteria bind to the cells.

This study was supported by Public Health Service grants AI18768 and AI-22380 from the National Institute of Allergy and Infectious Diseases. I am the recipient of Research Career Development Award K04-AI-00584. I acknowledge the assistance of Lorraine Kasmala, Edmund C Metcalfe, and Guillermo E Garza in performing the various experiments, and thank Ms Diana Hinojosa for typing this manuscript.

\section{References}

1 Meingassner JG, Mieth H, Czok R, Lindmark DG, Muller M. Assay conditions and the demonstration of nitroimidazole resistance in Tritrichomonas foetus. Antimicrob Agents Chemother 1978:13:1-3.

2 Symposium on trichomoniasis. Basle, 20 October 1981. Gynäkol Rundsch 1983;23 suppl:1-88.

3 Pavić R, Stojković L. Vaccination with Solco Trichovac. Immunological aspects of a new approach for therapy and prophylaxis of trichomoniasis in women. Gynakol Rundsch 1983;23 suppl 2:27-38.

4 Milovanović R, Grc̃ić R, Stojković L. Serological study with Solco Trichovac, a vaccine against Trichomonas vaginalis infection in women. Gynakol Rundsch 1983;23: suppl 2:39-45.

5 Stojković $L$. New evidence elucidating the mechanism of action of gynatren/Solco-Trichovac. Gynakol Rundsch 1984;24 suppl 3:29-37.
6 Bonilla-Musoles F, Sanches-Pena JM, Pellicer A, Guevara F, Ziegler WJ. A vaccine against vaginal trichomoniasis in humans. A temporary solution of the problem? Revista Española de Obstetricia y Ginecologia 1983;42:777-89.

7 Gombošová A, Demeš P, Valent M. Immunotherapeutic effect of the lactobacillus vaccine, Solco Trichovac, in trichomoniasis is not mediated by antibodies cross reacting with Trichomonas vaginalis. Genitourin Med 1986;62:107-10.

8 Alderete JF. Antigen analysis of several pathogenic strains of Trichomonas vaginalis. Infect Immun 1983;39:1041-7.

9 Alderete JF. Identification of immunogenic and antibody-binding membrane proteins of pathogenic Trichomonas vaginalis. Infect Immun 1983;40:284-91.

10 Alderete JF, Pearlman E. Pathogenic Trichomonas vaginalis cytoxicity to cell culture monolayers. British Journal of Venereal Diseases 1984;60:99-105.

11 Alderete JF. Enzyme linked immunosorbent assay for detecting antibody to Trichomonas vaginalis: use of whole cells and aqueous extract as antigen. British Journal of Venereal Diseases 1984;60:164-70.

12 Alderete JF, Garza GE. Specific nature of Trichomonas vaginalis parasitism of host cell surfaces. Infect Immun 1985;50:701-8.

13 Alderete JF, Suprun-Brown L, Kasmala L. Monoclonal antibody to a major surface glycoprotein immunogen differentiates isolates and sub-populations of Trichomonas vaginalis. Infect Immun 1986;52:70-5.

14 Alderete JF, Kasmala L. Monoclonal antibody to a major glycoprotein immunogen mediates differential complementindependent lysis of Trichomonas vaginalis. Infect Immun 1986;53:697-9.

15 Alderete JF, Demeš P, Gombošová A, et al. Phenotypes and protein epitope phenotypic variation among fresh isolates of Trichomonas vaginalis. Infect Immun 1987;55:1037-41.

16 Steinbüchel A, Müller M. Anaerobic pyruvate metabolism of Trichomonas foetus and Trichomonas vaginalis hydrogenosomes. Mol Biochem Parasitol 1986;20:57-65.

17 Martinotti MG, Martinetto P, Savoia D. Adherence of Trichomonas vaginalis to cell culture monolayers. Eur J Clin Microbiol 1986;5:320-3. 